\title{
Remapping Australia: Murray Bail's New Topographies of the Self in the Notebooks
}

\section{Marie Herbillon}

\section{(2) OpenEdition \\ 1 Journals}

Electronic version

URL: http://journals.openedition.org/ces/281

DOI: $10.4000 /$ ces.281

ISSN: 2534-6695

Publisher

SEPC (Société d'études des pays du Commonwealth)

\section{Printed version}

Date of publication: 1 April 2018

Number of pages: 9-22

ISSN: 2270-0633

\section{Electronic reference}

Marie Herbillon, "Remapping Australia: Murray Bail's New Topographies of the Self in the Notebooks", Commonwealth Essays and Studies [Online], 40.2 | 2018, Online since 05 November 2019, connection on 05 April 2021. URL: http://journals.openedition.org/ces/281 ; DOI: https://doi.org/10.4000/ces.281

\section{cc)}

Commonwealth Essays and Studies is licensed under a Licence Creative Commons Attribution - Pas d'Utilisation Commerciale - Pas de Modification 4.0 International 


\section{Remapping Australia: Murray Bail's New Topographies of the Self in the Notebooks}

The Australian writer Murray Bail's Notebooks feature a change of stance that interrogates the self-place relationship: initially dominated by an ideal of placelessness, they then seek to forge new bonds with a reimagined homeland. This essay examines the political implications of this paradigmatic shift. Arguably, the sense of identity that finds expression in this unconventional autobiography depends, in part, on a radical reconceptualisation of the Australian space.

In the past few decades, a number of critics - among whom the authors of The Empire Writes Back - have maintained that "a major feature of post-colonial literatures is the concern with the development or recovery of an effective identifying relationship between self and place" (Ashcroft et al. 8). From its inception Australian literature in particular has been largely dominated by the idea of place. The contemporary Australian writer Murray Bail is no exception to this rule: throughout his fiction, he has regularly interrogated the relationship between national landscape and cultural identity. In his introduction to The Faber Book of Contemporary Australian Short Stories (1988), Bail himself recognised that the landscape had long been (and still was in the 1980s) "the dominating force" (xv) in Australian literature and art in general.

Yet, it is worth noting that Bail's Notebooks (first published in 1989 under the title Longhand: A Writer's Notebook and reissued sixteen years later in an augmented version soberly entitled Notebooks 1970-2003) engage with the issue in a more oblique manner. This border-crossing text, which collates first- and third-person entries, also features a crucial change of stance. While the first part (started in London in the early 1970s) seems dominated by an ideal of placelessness and a general sense of unbelonging, the second half (chiefly written in Sydney from the late 1980s onwards) arguably displays a wish to create new bonds with a home country now perceived as essentially heterogeneous. ${ }^{1}$

Taking its cue from Bakhtinian theory, this essay will rely on a chronotopic analysis so as to examine the potentially political implications of this paradigmatic shift. Ultimately, I aim to show that Bail, as he breaks with traditional - i.e., historical - definitions of autobiography (notably in terms of self and genre), not only suggests that a genuine sense of Australianness necessarily depends on a large-scale reconceptualisation of the Australian space, but also that a modern, i.e., plural, conception of identity, such as it finds expression in the hybrid genre invented with the Notebooks, inevitably rests on much more than a mere sense of place.

In the mid-1970s, the French theorist Philippe Lejeune defined autobiography as a "retrospective prose narrative produced by a real person concerning his own existence,

1. Although it was released in 1989, Longhand was written between 1970 and 1974, when the author was residing in London while travelling around Europe. I will use this edition every time I refer to those early years; all entries written between 1988 and 2003 will thus be taken from the most recent edition (Bail had, by then, returned to Australia, from where he undertook various journeys abroad). This will allow me to distinguish clearly between two distinct time-frames which I will also call Part I and Part II respectively. 
focusing on his individual life, in particular on the development of his personality" ("The Autobiographical Contract" 193). In a couple of remarkable articles dedicated to what he names "geotobiographies," Frédéric Regard exposes this definition as doubly restrictive, ignoring as it does the issue of the autobiographer's spatial positioning. Firstly, this definition of autobiography lays the emphasis on "an essentially historical element" ("Topologies" 19), which largely overlooks the fact that the speaking subject is also geographically placed in the physical universe. Secondly, it fails to highlight that "discourse spatializes the subject in [an even] more decisive fashion than [...] 'natural' geography" (17). If this definition could - in Lejeune's own view - accommodate various exceptions, one single sine qua non condition had to be fulfilled if a text was to be classified as an autobiography: a relationship of identity had to exist "between the author, the narrator and the protagonist" (193). The main problem with this definition does not so much lie in the fact that it postulates authenticity, insofar as Lejeune himself is careful to differentiate between this ambiguous notion and those of absolute transparency and referentiality: since it is obviously vain to hope that "objective" truth can be reached through autobiographical writing (or, for that matter, through any kind of discourse), it is the "intention on the part of the author" (Anderson 2) to tell his/her truth, i.e., a form of sincerity, that guarantees autobiographical "authenticity." In this context, the reader has no choice but to believe the author as to the fact that the latter is saying the truth about him-/herself. This is what Lejeune has called "the autobiographical contract" in his well-known Pacte autobiographique. Arguably, the weakness of Lejeune's definition has more to do with the fact that it posits introspection as a natural process, whereas the introspective impulse, for the advent of which the "identity between observer and observed" (i.e., between narrator and author) is a problematic "precondition" (Marcus 69), was almost simultaneously called into question - and ultimately deemed impossible - by the poststructuralist and deconstructionist movements (see infra). Drawing on the theories developed by Émile Benveniste, in which the French linguist discriminates between the subject of the enunciation (the autobiographical "I" of the utterer) and the subject of the utterance (the "real" "I" of the author), Lejeune, for his part, appears to suggest that the self is composed of two identical entities, namely the narrating "I" of the autobiographer and the author as a real person, and yet that the former can take the latter as his/her object, as if these entities were also distinct, or separable.

There is no reason to suppose that Bail is violating Lejeune's pact in the Notebooks, namely that he is being insincere by not being the one he implicitly claims he is, even if only a small minority of entries are historically, or factually, verifiable in this respect. Strictly speaking, i.e., from what is commonly known of Murray Bail's life as a writer, it can be ascertained that the couple of specific public events to which the text refers firstly, the fact that he received a prize called "Premier's Award" (Notebooks 202) on 16 September 1988 in Melbourne, for his novel Holden's Performance, and secondly his meeting with the "Queen" of England at "B. Palace" (272) - occurred to the person whose name appears on the Notebooks' cover. However, this does not amount to asserting that the textual "I" unambiguously designates the author of the book: it would be bold, even paradoxical to assume that the I-entries indeed have the ability to give us direct access to the author's mind, life and feelings, as - somewhat deceptively - suggested by the classic conception of authorship on which the autobiographical contract is premised, and to 
which Lejeune himself could never entirely subscribe. ${ }^{2}$ As early as the 1970 s, poststructuralism radically challenged this view of the author as a truthful and authoritative entity controlling the meaning of his/her works, as well as the related, romantic, notion of a unified and authentic selfhood. In fact, the poststructuralist critique of these concepts can be located in the broader context of a new paradigmatic shift taking place a century and a half after the previous one, which led to the emergence (around 1800) of autobiography and its development as a genre. In this sense, as Laura Marcus indicates, "the critical and theoretical interest in autobiography which has gathered pace since the 1950 s," and indeed "the growth of "autobiographical studies" (180) themselves, "can $[\ldots]$ be understood as a response to, or an aspect of, the intense debates over subjectivity in the latter part of the twentieth century" (147).

In his experimental autobiography originally published in 1975 (and first translated into English in 1977), Roland Barthes by Roland Barthes, the latter already pointed to the utterly discursive nature of "the subject," declaring that it was "merely an effect of language" (79, original emphasis). Let us note in passing that Lejeune, who came to recognise the rhetorical dimension of subjectivity, remained convinced that the autobiographical contract could be "sealed by the name of its signer" (209), as if the latter, by virtue of his/her location at the "outer edge" (210) of a text, was not part and parcel of writing: the author's personal name, onto which the "I" is displaced, is seen as being "at once textual and indubitably referential" (211), i.e., as "the only mark in the text of an indubitable "outside-of-the-text," designating a real person" (199). In poststructuralist and deconstructionist accounts, this idea of an isomorphism between proper name and authorial authenticity is resolutely invalidated: the name(s) featured on the cover of a book is (are) clearly as immersed in language as the rest of the text, and thus emerge(s) as an "insufficient marker of authenticity" (Marcus 257). In this regard, Derrida points out that "the proper name" or signature, which is as texturised as the "I" featured in the body of the autobiography, "is not to be confused with the bearer [...] of the name" (Ear 53), i.e., the "real" self. As for Paul de Man, he uses a different terminology to make a similar point. In his groundbreaking essay "Autobiography as De-facement" (1979), he argues that since the writer's self is always mediated through language, the writing of autobiographies necessarily implies some sort of displacement and that a crucial distinction thus needs to be made between, on the one hand, the name on the title page or signature, which pertains to the author's rhetorical "I," and, on the other hand, the proper name referring to its bearer, i.e., the autobiographer's real personality. As Marcus aptly remarks in her discussion of de Man's work, "autobiography imports alterity into the self by the act of objectification which engenders it" (203). In the same essay, de Man explicitly attacks Lejeune because he "uses 'proper name' and 'signature' interchangeably" and contends that, by contrast, "the name on the title page is not the proper name of a subject capable of self-knowledge and understanding, but the signature that gives the contract legal, though by no means epistemological, authority" (71). For de Man, the writer's self is thus hopelessly divided and can only be textually, i.e., imperfectly, reconstructed. Just as most fiction encapsulates an autobiographical component, so do autobiographies - as Linda Anderson puts it - "produce fictions [...] instead of the self-knowledge they seek" (13). The poststructuralist and deconstructionist critics then

2. In his later work, he refuted "some of the more absolute claims" (Marcus 193) he made in his famous essay. 
not only foreground the subject's fundamentally split character: next to this idea of a radical self-division, they also highlight - unlike Lejeune - the inextricable "coincidence" (Barthes 55) of the two entities constituting the self and, therefore, the impossibility of introspection. Since the "real" self cannot be dissociated from the autobiographical one, the "I" is condemned to being "im-pertinent": having "no referent" (56, original emphasis) outside language, it cannot, in other words, take itself as an object. This is not to say, however, that the self does not pre-exist language. Indeed, the prelinguistic self is no more absent or non-existent than it is unitary, static or substantial. The myth of the self defined as a "rational concretion" (Barthes 119) and represented in English by a single and solid straight line should thus also be dispelled: there is no such thing as a primary, naked or pure "I" that would "simply lie beneath veils, awaiting the moment of revelation" (Marcus 122). Rather, as Barthes further suggests when he refers to the fundamental "inconsistency of the subject, his atopia" (86), the so-called "real" self is like a shapeless, insubstantial and inessential entity that must be written into existence. I will return below to the shape(s) possibly taken by non-introspective self-writing. In other words, discourse forever precludes the discursively spatialised subject from reaching his/her "ipseity" (see Regard, "Topologies" 18 and "Géotobiographies" 14), i.e., a sense of oneness with him-/herself. The so-called "metaphorists" (Roy Pascal, James Olney, Jean Starobinski, etc.) also advocated the subject's "literarity" against the "literalness" (see Regard, "Géotobiographies" 17, 19) defended by Lejeune and his proponents (the "literalists") but both traditions (with the exception of Derrida, who - in Margins of Philosophy (1982) - put forward the idea of the writing self's inner "spacing") remain, as Regard notes, "attached to a single and unchanging paradigm, that of an individual subject cut off from the world" ("Topologies" 20).

Regard further contends that the joint determiners of the life-writer's spatial placement are, on the one hand, his/her objective location, which can be approached in chronotopic terms, and, on the other, a positioning vis-à-vis "hermeneutic models involving a conception of space" ("Géotobiographies" 13, my translation for all excerpts from this text). For Bakhtin, the concept of chronotope (literally time-space), which is borrowed from mathematics but can - as his examination of Western literature demonstrates - be productively transposed to literary studies, should be understood as expressing "the inseparability of space and time" (84). Although the term is said, in The Dialogic Imagination: Four Essays by M.M. Bakhtin, to function as "the primary means for materializing time in space" (250; more specifically, it is applied to concrete places, like roads or rooms, fusing spatial and temporal indicators), I will use it more neutrally (more liberally, maybe), as a way of referring to the abstract, non-linguistic intersection of spatial and temporal parameters in Bail's autobiographical account. In this respect, it can be upheld that the autobiographer's chronotopic placement mirrors his positioning towards extratextual discourses on place (or, by extension, on national identity), which may - to some extent - have contributed to shaping his perception of these categories.

Let me exemplify this: in the early 1970s, Australia was still characterised by a marked conservatism and nationalism. Conceivably, such a mind-set was tightly linked to archetypal representations of the local landscape as unified and monolithic - a type of connection Bail has relentlessly addressed and problematised in his fictional writings. It also resulted in cramped definitions of national identity. As Brian Castro puts it in Looking for Estrellita, a collection of essays in which he emerges as both a practitioner and a 
theorist of autobiography, identity became, at the time, "the pretext for the suppression of heterogeneity" (29). In Part I (the one written in Great Britain between 1970 and 1974), Bail seems to be contaminated, on a couple of occasions, by this stereotypical view of his native country as nothing but a hot and dry place. Witness the following entry:

When I think of "Australia," I first see its shape. It is quickly followed by scenes of slow-moving dryness, muted colours, and some of the great white trees. Of people in general, it is often young, flushed mothers in sleeveless cotton dresses yanking or carrying children on the hot city asphalt. (Longhand 30)

Elsewhere, he states: "Sometimes, 'Australia' appears to me as all rocks (dry, hot)" (Longhand 109). If these comments are rather explicit compared to many other entries, they still resist interpretation, which can be ascribed to Bail's general refusal to go beyond the level of seemingly objective - but often deceptively transparent - description in the Notebooks. The fact that the word Australia is placed between quotation marks in the two above-mentioned cases nevertheless seems to indicate a willingness on the author's part to distance himself from these stock depictions of his homeland. By the same token, brief descriptions obliquely castigate some Australians' propensity for national pride. For instance, a presumed relative of his then wife Margaret Wordsworth (see Ackland 25 ) is portrayed in this way: 'M.'s aunt from Queensland: long face, wrinkled vertically (unusual). Broad sensible dress. Firm disgust at foreignness; but loud about Australia" (Longhand 25). Later on, he reports and laconically comments on a conversation between an Italian guide and an Australian tourist: “Guide: 'Do you all speak English?' / Australian, loudly: 'Can you manage Australian?' / A form of pride” (Longhand 117).

However, this first section can be said to move towards what Castro has named "a conscious extinction of place" (9): on the whole, Australia is rarely mentioned and the pronoun "we" is never used as a referent for Bail's fellow Australians. Furthermore, a sense of homelessness, concerning both his country of adoption (where he temporarily chose to live, for reasons which remain undisclosed, between mid-1970 and late 1974) and his birthplace, is asserted throughout. The impression of "not [being] part of all this" (Longhand 1) he had upon his arrival at Heathrow airport in June 1970 has not left him shortly before his return to the fold, as suggested by this entry: "Definite feeling of unbelonging - definitely" (139). As for the notion of home, which features in one single entry, it is immediately disavowed by the three words following it, namely: "Wherever that is" (134).

It may not seem coincidental, by contrast, if Part II, which covers a fifteen-year timespan, starts in Sydney in 1988 (after an equally long gap in the writing). It is indeed in the late 1980s that some writers and critics locate "the advent of multiculturalism" (Castro 31) in Australia. This concept is, of course, a highly controversial one in the Australian context. A scholar like Ghassan Hage has criticised the limited scope of Australia's multiculturalism and exposed what he termed "white cosmo-multiculturalism" (205) as a type of rhetoric which, in practice, has tended to contain and regulate racial and cultural difference. Although Bail's novel acknowledgement of his country's geographical variety (see infra) should obviously not be seen as a direct consequence of Australia's multicultural politics, it may still have something to do with the author's sensitivity to a new Zeitgeist rooted in more heterogeneous conceptions of space and identity, which progressive writers like himself - together with various other factors - may also have 
contributed to shaping. It would thus come as no surprise that Bail should feel more in line with a country where cultural hybridity would no longer be "synonymous with inauthenticity" (Castro 10). His own perspective on the local place is, at least, deeply modified. In his distinctively terse way, he is now keen to insist on Australia's inexhaustible geographical diversity, as attested by this entry: "Another and then another and yet another landscape" (Notebooks 206). Similarly, he takes to depicting atypical - i.e., non desert-like - landscapes, for instance this one which is covered in snow (near Oberon): "Snow all the way up the trunks of eucalypts: white and grey-white. Snow and cold are always a reminder of the harshness of this isolated planet, and how humans have softened it, to remain living" (215). He is also more inclined - if relatively so - to rely on first-person plural pronouns, which notably express a nascent identification with the Australian people. Having previously established his belief in topographical variety, he even attaches, on one occasion, such a pronoun to the delineation of a fairly traditional landscape, which then becomes one among many possible representations of Australia: "Around Wilpena, the colours are naturally ours: silver-greys, pale browns. The pink of galahs" (258). At some point, he even observes that "hot, foreign places seem to produce homesickness" (265). Insofar as this non-I-entry can be applied to himself, it might imply that his new awareness of Australia's territorial multiplicity now allows him to experience this feeling, which he defined earlier on as the "habits of a landscape acquired over time" (Longhand 30).

The very possibility of a change in personality and thus in viewpoint (including vis-à-vis his motherland) is actually alluded to in the Notebooks. Whereas Bail seemed convinced, in Part I, that "[he could] remain the same. Easily" (Longhand 11), he claims, in an entry dated 8 March 1999 in Part II, that "in the past ten years [he has] become more complex," adding that "it has made [him] more interesting, and yet less attractive" (Notebooks 272). Significantly, this paradigmatic shift is echoed in the fiction. In Holden's Performance (1987), many characters are subjected to the literal influence of a simplified environment (either urban or rural), with a view to parodying their allegiance to a nationalistic doctrine or simply their excessive identification with their archetypal motherland. The central protagonist is, for one, a grotesque allegory of his country: physically huge but ontologically empty, Holden Shadbolt comically problematises the seductiveness of place as a matrix of cultural identity. In the later novels, Bail's approach to this classic theme in Australian literature nevertheless takes a more serious turn. The complex, hybrid spaces that serve as backgrounds to Eucalyptus (1998) and The Pages (2008) obviously parallel the author's earnest, methodical attempts to debunk, like Patrick White before him, the myth of "the Great Australian Emptiness" (White 157). In Eucalyptus, for example, he forces us to remember that the singular genus of the title is a linguistic construct concealing myriad eucalypts: blinded as we are by the most common specimens, we just cannot see the wood for the trees. Turning as many trees as he can into metonyms for his country, Bail thus refutes the widespread accusations of uniformity that are regularly directed at the Australian landscape and celebrates a land that is actually as dazzlingly diverse as the "trees [which] compose [it]" (Eucalyptus 16). In The Pages, he similarly questions the idea that the vast, arid spaces of Australia must necessarily induce cultural - philosophical rather than literary, in this case - barrenness, inciting us to remember that the Australian space is a heterotopic palimpsest, the geographical 
variety and historical layering of which should be uncovered rather than obscured by enduring archetypal representations.

In the Notebooks, the author's new rapprochement with a reconceptualised landscape no more lapses into complacent national devotion than it does in the fiction. Bail is indeed careful to suggest that he is never entirely at one with Australia. Although he feels "welcomed [...] back" (240) in Sydney, where he settles in the late 1980s, he keeps moving from one of the city's neighbourhoods to the next. These frequent changes of address, as well as his realisation that his mobility amounts to "a form of evasion" (241), definitely resonate with the words of Henri Lefebvre, who, in The Production of Space, saw the notion of home as "an imaginary encoding that belongs to an extinct past" (see Regard, "Topologies" 22). More importantly, it should be stressed that, on the whole, the entries pertaining to other topics far outnumber those devoted to Australia. In this sense, the Notebooks break free - and doubly so - from the traditionally postcolonial theme of the relationship between self and home country, partly because of the narrative transpositions to various foreign settings, but also because the issue of place now emerges as one among many features of a text that engages more broadly - as we will see below - with the notion of identity. In the aforementioned introduction to The Faber Book of Contemporary Australian Short Stories, Bail also argued that "transport[ing] themselves or their subjects overseas" was a way for Australian writers of "gaining [...] an instant complexity" (xvi). Significantly, Bail followed his own advice in the Notebooks, so much so that these often read like a travel book in which he deterritorialises himself further and further away from either the old imperial centre or from Australia. If, in the London notebooks, the author is naturally led to focus on the urban landscape of the British capital rather than on his homeland, he also relates several trips to nearby countries (namely France, Spain, the Netherlands, Belgium, Switzerland and Germany), then to Northern Africa (Morocco) and Russia. Likewise, the second section recounts Bail's various journeys to Europe (including, this time, "exotic" destinations like Iceland), as well as to North America (Canada and the United States) and West Africa (Senegal, Mauritania or Mali), where he was obviously too engrossed in an often utterly defamiliarising environment to concentrate on the matter of his own national identity. Because it virtually obliterates locatedness and compels the traveller to direct his/her gaze towards the outer world, travel definitely contributes to shaping fluid, rather than stable, identities - and it does so in each part of the Notebooks.

As a matter of fact, this outward-turning gaze can be regarded as the hallmark of the entire book, which seems to conceive of the autobiographical form as an ongoing dialogue with the outside world. Each section of the Notebooks indeed consists of an apparently transparent textual collage that conflates reported conversations, quotations, casual observations, brief comments on an array of topics ranging from art to language, as well as newspaper cuttings and obituaries. This Bakhtinian dialogism makes for a deeply heterogeneous text, which deviates (both in terms of self and genre) from the traditional definitions of autobiography as an introspective, retrospective, historical and essentially European genre. Focused on the main events of a great man's existence and on the "evocation of [his] life as a totality" (Marcus 3), these formally and culturally dominant autobiographies tend to present selfhood and genre - inseparable categories in autobiographical criticism - as stable and coherent entities: they are not only generically homogenous or unitary, but they also ascribe a central place to a self conceived 
as monadic, static, centred, exemplary and sovereign. By contrast, Bail's extrospective, non-retrospective and spatial Notebooks experiment with the conventions of the genre, allowing their author to develop what could be named a philosophy of the extimate, which turns, with time, into a genuine poetics.

Although Bail hardly expresses reservations about introspective literature until the end of Part II (see infra), his repudiation of introspection is clearly textualised in the Notebooks since the latter bear less resemblance to a journal intime in which the author would withdraw into his shell than to a journal extime, in the phrase coined by the French writer Michel Tournier ${ }^{3}$ to define his own autobiographical writings. Autobiography, which has often been likened to the process of looking at oneself in a mirror, thus becomes synonymous with holding this mirror out to the world. If the self, as Tournier - like Barthes before him - seems to think, is "insubstantial" and therefore uninteresting as such, the autobiographer should, instead, attempt to detect in the external world (which is not limited to national space), the small yet significant events that deserve unmitigated attention. Tacitly but firmly, Bail's own hybrid collage asserts the superiority of the outside over the inside, so much so that he could probably have declared, with Tournier, that "reality is infinitely beyond the resources of my imagination and keeps filling me with surprise and admiration" (Journal extime 12, my translation). Like Frank Delage, the protagonist of his latest novel, who carries around notebooks "for jotting down things he had read or heard, the way some people pick up cigarette butts, they could be useful one day, not only maxims, although most of them were, unusual phrases, descriptions too, he liked the sound of single words" (The Voyage 10, emphasis added), Bail thus embarks on a quest for what he terms, in The Voyage, "the poetic unexpected." This spiritual quest, which appears as a constant in the Notebooks as a whole, consists in the perpetual desire and attempt to encounter "new knowledge" (53) in the real, which then turns into an enchanted place where the "ordinary" can reveal itself. Adopting the posture of the philosopher (of the phenomenologist, in particular), Bail lets the world speak before subjecting all that catches his attention to description, as if the facts of life could be laid bare. This descriptive strategy, which refrains from indulging in emotion, explanation or analysis, is often - as Marcus observes - "accompanied [...] by [a] process of estrangement" (114) which reproduces or even reinforces the sense of surprise the autobiographer experienced in the first place. This art of serendipity is not simply a matter of luck; the discovery of the unexpected is also the result of human agency insofar as it implies a great mental availability and a resolute opening to newness.

In Part I, Bail repeatedly uses the term "alert(ness)," which clearly thematises the type of sagacity that is supposed to go hand in glove with his extrospective attitude. When he leaves the hospital where he was treated for a tropical disease, for example, he says he has been observing everything "with special alertness" (Longhand 43). Later on, he emphasises an "extreme alertness to almost all things" (Longhand 58). Elsewhere, he notes as a possible consequence of his increased receptiveness that some objects have the power of "asserting themselves" and "coming forward at [him], in their absolute es-

3. Although the Notebooks contain no reference to his Journal extime (published in 2002), Tournier's novelistic work is cited with admiration in two of the few entries explicitly expressing Bail's literary preferences. The first one reads as follows: "With little warning I read a novel of commanding force, intelligence: The Erl King. Through his thoughts the author himself (Tournier) almost becomes the most interesting character" (Longhand 91). The second one, which opposes introspective to mythical literature, will be discussed in more detail below. 
sence" (Longhand 97). With the following quotation, also featured in Part I, Bail invokes Goethe in order to address the way in which the latter evolved a connection with the outside world, which exerts a constant influence on him:

"I sought to free my inner life of every alien influence, to look with love on all around me, and allow all beings, from man downwards to the lowest comprehensible creature, to act upon me, each after his own kind. Thus arose a wonderful affinity with the several objects of nature, and a heartfelt concord and harmony with the whole, so that every change, whether of place and country, of hour and season, or of any other part of the natural order, affected me profoundly." - Goethe (Longhand 47-8)

As he quotes Goethe, Bail presumably seeks to signal a filiation with the German writer, an autobiographer and eulogist of extrospection, thereby distancing himself from other autobiographical models notably provided by Augustine, the founding father of introspective autobiography.

As early as that period (i.e., the beginning of the 1970s), Bail nevertheless seems aware of the fact that his desire for exteriority and the quest for defamiliarisation it entails tend to induce a propensity for "using the word ' $\mathrm{T}$ ' too much," which he then sees as "a sign of inexperience" (Longhand 13). In Part II, Bail's persistent distrust of introspection leads him to ponder further on the most appropriate narrative treatment of the "I." For instance, the next entry - although it ironically contains a first-person pronoun - explicitly testifies to his distaste for confessional (as well as "effect-oriented") literature:

It makes no difference whether literature is European, American, British, or Australian, as long as it allows me to enter and contemplate. Prefer inventions, those that more or less reach the area of myth (the broadest sense). Kadare, Tournier, Marguerite Yourcenar etc.; Madame Bovary - "myth." The Illiad [sic]. Little interest in literature - or painting, music - produced merely for effect. The confessional, self-analysis in the first person which is now common: it's difficult, though not impossible, for it to enter "myth." (Notebooks 282, original emphasis)

Other entries firmly denounce introspection, stigmatising any autobiography that would limit itself to a narrow kind of self-analysis (see 280). Next to this succinct theorisation, a real effacement of the " $\mathrm{I}$ " should be pointed out in this portion of the text. In this respect, it is worth noting that Part I contains, proportionally, twice as many entries in the first person as Part II. Like Barthes, Bail is careful to disperse the autobiographical self by multiplying the modes of self-reference, i.e., by using a range of pronouns other than the "I" to refer to himself. At times, he opts for the second-person pronoun "you"; elsewhere, he addresses himself in the imperative mode. In an entry like the following, which contains both an existential and a self-reflexive dimension, he tersely combines the two methods: "You're here briefly - work, give shape" (260). In a semantically related entry, which is also the Notebooks' concluding comment, he includes himself in a collective "we": "No use saying: if only we could live longer, there is not enough time etc. The brevity of life is in the design; it applies to every one of us" (306). A few pages earlier, an uncommented quote by Montaigne aptly emphasised the inevitable multiplicity, indeed the permanent dissemination of the self:

"Anyone who turns his prime attention on to himself will hardly ever find himself in the same state twice. I give my soul this face or that, depending on which side I lay down on. I speak about myself in diverse ways: that is because I look after myself in diverse ways. Every sort of contradiction can be found in me: timid, insolent, chaste, 
lecherous: talkative, taciturn: tough, sickly: clever, dull, brooding, affable; lying, truthful: learned, ignorant; generous, miserly and then prodigal - I can see something of all that in myself..." - Montaigne (280)

In view of the pronominal strategies described above, it can legitimately be assumed that Bail shares this position.

As (s)he turns outward in this way, the writing subject thus becomes what Barthes names "an echo chamber" (74), i.e., (s)he disperses him-/herself in reaction to the objects, people, situations, sights, words, discourses, systems, etc. which surround him/her. By reinforcing this dispersion in Part II, Bail strengthens the poetics of the extimate started in Part I. As indicated earlier, the notions of self and genre are closely interrelated in the field of autobiography, where the "dispersion" (Barthes 143) to which extrospection subjects the self converges with the idea of "writing as [...] an unconditional dispersion" (136). As it writes itself into existence, the autobiographer's "dispersed" self further disseminates itself and turns into a textual "patchwork of reactions" (143). More than any other narrative form, extrospective writing thus spatialises the self, even as it entails a generic impurity that has been criticised by the proponents of traditional, i.e., introspective, autobiography. As Marcus puts it, "the demand for generic purity runs through auto/biographical discourse" and is "often linked to a strong rejection of the idea that it is environment that determines character" (61). The "scattered" subject (Barthes 158) writes "by fragments" (92) and proceeds "by addition" (94): according to Barthes, "the fragments are then so many stones on the perimeter of a circle" (92-3), the centre of which would be too vague and elusive to be grasped. As Barthes further explains, "each piece is self-sufficient" (94) and no new fragment is ever the last one: it "is nothing but a further text, the last of the series, not the ultimate in meaning" (120, original emphasis). However, all these fragments gradually compose something like a Chinese portrait. As the autobiographer writes "in brief bursts" (93) and attempts "to resist the last word" (94, original emphasis) on him-/herself, (s)he allows a figure, his/her own, to delineate itself between the lines.

The rhetorical recession of the self described above may also be invested with a political significance. On the part of a white Australian writer like Bail, it might indeed partake of a wish to dissolve a specific European legacy, that of the solid and singular "I," the centrality of which has, at the turn of the $19^{\text {th }}$ century, not only given birth to autobiography, but also played a symbolic role in the rise of colonialism. This is a point raised, for instance, by Marcus, who views colonisation and autobiography as "a product of the same impulses" (157). Likewise, Regard sees "a coincidence between the emergence of the autobiographical tradition and the hegemonic practices of Western modernity" ("Géotobiographies" 20). More particularly, he maintains that "the isolation' of the Western subject has always gone hand in hand with a hegemonic centralization that extended into the constitution of the great European Empires" and into "a world-order in which the Other was perceived as a threat" (21). According to Regard, this dogma, "through which the [European] individual has construed himself as the absolute centre of the world" has long obscured the crucial issue of the "geography of the self" (20). For a white writer like Bail, the dispersion, or partial dissolution, of the autobiographical "I" could therefore take on a political character, this decentralisation allowing him, on the one hand, to construct an identity that would not be the mere re- 
plica of a dominant subjectivity and, on the other, not to perpetuate the oppression - be it discursive - of Australia's indigenous populations.

However, the erasure of the "I" is - as previously pointed out - not total, which would be neither realistic nor desirable, first because, as Bail himself notes, "it is almost impossible to live without vanity" (Notebooks 304), and also because the "I" represents a symbolic but necessary form of agency in an Australian context where identities in construction might be even more tentative than anywhere else. ${ }^{4}$ Furthermore, this recession of the "I," which - as attested by the many biographical fragments incorporated in Part II - is paired with a growing interest, on the autobiographer's part, in lives other than his own, ${ }^{5}$ is above all grammatical: even if the gradual effacement of the pronoun strengthens the (deceptive) impression of transparency and objectivity emerging from the text, the writer's autobiographical self (his "I") subsists in the form of a point of view (i.e., an "eye"), the neutrality of which is obviously illusory. In other words, the recession of the "I" is intimately linked to the development of a genuine poetics, not only of the extimate but also of the unexpected, which seeks to discard both an invasive self and heavy stylistic effects in order to textually re-create a sense of amazement (or even of wonder) instead of merely witnessing it in the outside world and describing it phenomenologically. The following entries are particularly relevant in this connection: "As she watched a woman on the street holding a baby up to her face saliva filled her mouth" (Notebooks 209); or: "From train (near Woy Woy): old turquoise-coloured barge rotting in khaki water. Man opposite, asleep, smelling like a wet dog" (284). Insignificant though they may seem, these two excerpts show how the writer silently worms his way into apparent descriptions (in which I have italicized the most creative segments) ${ }^{6}$ to create surprise, not only by defamiliarising the real in order to make its strangeness palpable, but also by initiating, within the Notebooks, a movement towards textualisation based on a friction (not to say a fusion) between the categories of "fact" and "fiction."

Although they were systematically categorised as non-fiction by his publishers, Bail's Notebooks thus function as a textual locus where both reality and self are creatively rendered. While Lejeune and de Man expressed their dissatisfaction with the impossibility to make a clear-cut distinction between autobiographical and fictional texts, Bail deliberately blurs the boundary between fact and fiction in his Notebooks. Not only does his autobiographical account offer several ideas that were subsequently exploited in his novels, but it also exemplifies the process - also thematised and textualised in Eucalyptus - by which "experience" is inevitably, and should always be, transformed into "texture" (258).

Envisioned as definitely multiple, identity as approached by Bail is also deeply dynamic, since the self does not exist as such, i.e., as a pure, naked and sovereign ontology, but can only be captured (though not contained) in the sustained interactive process of writing back to the world at large. For Bail, as much as for Barthes, this "zone of

4. It can, for instance, be argued that the exacerbated nationalism that has sometimes been observed in Australia and has tended to contaminate settler literature is but an extreme response among others to the sense of fragility, not to say the cultural inferiority complex, generated by colonisation.

5. The following entry exemplifies this tendency: "Man (in Provence) tells younger swimmer she cannot land on his property. Exhausted she falls back into water. He then allows her to land, giving his hand. They have an affair for two years; children. His wife, owner of the house where it all began, left him" (294).

6. It goes without saying that Bail could know neither if the woman's mouth, in the first excerpt, was actually watering, nor, in the second case, what the man he saw from the train was smelling. 
diffraction" (Barthes 153) where the self reverberates the real is, therefore, the sole albeit multi-dimensional - space where both reader and writer can catch a glimpse of the autobiographical "I."

As a "miniature reflector of the outer world" (Marcus 43), the self is bound to be as dispersed as it is multiple. Throughout the Notebooks, Bail thus endeavours to produce a space, or myriad narrative spaces, for the deployment of a plural, dynamic and dialogical self, which is, of course, more in keeping with the multicultural spirit prevailing - theoretically, at least - in Australia from the late 1980s onwards than with the dominant nationalistic creed of the early 1970s (partly countered, as I said, in Part I). As demonstrated by the frequent geographical deterritorialisations and by the constant interplay with the outer world, Bail attempts less to preserve enshrined ideas of place than to open up spaces which could then be termed "topological" (instead of "topical"), in accordance with the typology elaborated by Michel de Certeau in The Practice of Everyday Life.

In a previously quoted critical article, Regard further contends that "topologies of the self rest on tropologies," i.e., that "tropes spatialize the inscription of one's presence in the world" ("Topologies" 26). In the Notebooks, the autobiographer's spatial inscription seems to be produced by the articulation of two main rhetorical figures. On the one hand, each entry can be construed as a metonym of the self (which may account for Andrew Riemer's portrayal of Bail as "a consummate miniaturist"). On the other, the potentially infinite juxtaposition of these individual parts, the sum of which will always be exceeded by the self as a whole (however utopian this notion may seem to be), culminates in an image featured in both Barthes and Bail, that of "the ship Argo, of which the Argonauts gradually changed each part, so that they finally had a new ship without having to change its name or form" (Longhand 96). ${ }^{7}$ The Argonauts' mythical ship thus provides a convincing metaphor for the self as an irreducibly diverse and evolutional object despite unchanging appearances. This image also implies a belief that performativity prevails over permanence or sequence. Although the Notebooks, which contain a few dates, preserve a global sense of chronology, their discontinuous quality arguably undermines temporal linearity inasmuch as it has the potential to disrupt the sequential order. Indeed, like the philosophy produced by Wesley Antill (one of the protagonists in The Pages), they are composed of countless "self-sufficient entities" (Moore-Gilbert, Postcolonial Life-Writing 105 and "A Concern" 103) which can be read in any order. Instead of favouring "any particular [...] vantage point" or "the progressive development of a privileged Self, in relation to which events and other persons are arranged as 'background' [...], narrative attention is 'evenly distributed"' (Postcolonial Life-Writing 103). Because they are not retrospective, each of the autonomous autobiographical acts they consist of nevertheless contributes, with equal weight, to the performative constitution of the life-writer's subjectivity; in the same way as Ian Fairweather's "finest" work, Bail's own text is "a mosaic reality, where everchanging parts make up a whole" (Ian Fairweather 155). ${ }^{8}$

7. Barthes's version: “... the ship Argo [...], each piece of which the Argonauts gradually replaced, so that they ended with an entirely new ship without having to alter its name or form" (46).

8. This comment by the author (acting as an art critic in this case) relates to a Futurist canvas entitled Buffalo Ride (1959) and painted by this Scottish-born Australian artist to whom Bail devoted a monograph (first published in 1981 and reissued in 2009). 
In all, with the Notebooks, Bail invents a hybrid genre that draws all at once on autobiography (the conventions of which the author takes some liberties with), biography, travel literature ${ }^{9}$ and even fiction. As I have shown, this fractured, manifold form goes hand in glove with a plural and dynamic approach to selfhood, whereby a contemporary sense of Australianness is evolved through the dispersion of unified, static and potentially hegemonic identities. As he constructs his complex mosaic of discursive fragments, Bail not only exposes the essentialised self as an illusion, but he also performs a political act, insofar as he reimagines his homeland as a heterogeneous space with which new bonds can be forged. As Gregory Day put it in his 2005 review of the Notebooks, Bail "thankfully expands the official representation of the Australian literary imagination" (2) and puts forward a conception of identity in terms of which a sense of self and a sense of place need not be equated.

Marie HerbILLON

University of Liège, Belgium

\section{Works Cited}

ACKLAND, Michael. "Murray Bail.” Dictionary of Literary Biography (vol. 325): Australian Writers 1975-2000. Ed. Selina Samuels. Farmington Hills, MI: Thomson Gale, 2006. 24-30.

Anderson, Linda. Autobiography. London: Routledge, 2001.

Ashcroft, Bill, Gareth Griffiths, and Helen TifFIn. The Empire Writes Back: Theory and Practice in PostColonial Literatures. 1989. London: Routledge, 2002.

BAIL, Murray. Ian Fairweather. Sydney: Bay, 1981.

—. "Indian Notebooks 1969." Quadrant Twenty-Five Years. Ed. Peter Coleman, Lee Shrubb and Vivian Smith. St Lucia: U of Queensland P, 1982. 13-24.

—. Holden's Performance. 1987. London: Harvill, 2000.

- Introduction. The Faber Book of Contemporary Australian Short Stories. London: Faber and Faber, 1988. xiii-vii.

—. Longhand: A Writer's Notebook. Melbourne: McPhee Gribble, 1989.

—. Eucalyptus. 1998. London: Harvill, 1999.

—. Notebooks 1970-2003. London: Harvill, 2005.

—. The Pages. London: Harvill Secker, 2008.

—. Fairweather. Sydney: Murdoch, 2009.

- The Voyage. London: MacLehose, 2012.

BAKHTIN, Mikhail M. The Dialogic Imagination: Four Essays by M.M. Bakbtin. Ed. Michael Holquist, trans. Caryl Emerson and Michael Holquist. Austin: U of Texas P, 1981.

BARTHES, Roland. Roland Barthes by Roland Barthes. Trans. Richard Howard. 1977. New York: Farrar, Strauss and Giroux, 1989. Trans. of Roland Barthes par Roland Barthes. Paris: Seuil, 1975.

CASTRO, Brian. Looking For Estrellita. St Lucia: U of Queensland P, 1999.

DAY, Gregory. Review of the Notebooks 1970-2003. The Age. 23 December 2005. 2.

De Certeau, Michel. The Practice of Everyday Life. Trans. Steven F. Rendall. 1984. Berkeley: U of California P, 2011. Trans. of L'Invention du quotidien. Paris: Gallimard, 1980.

De Man, Paul. "Autobiography as De-facement." 1979. The Rhetoric of Romanticism. New York: Columbia UP, 1984. 67-81.

Derrida, Jacques. Margins of Pbilosophy. Trans. Alan Bass. Chicago: U of Chicago P, 1982. Trans. of Marges de la philosophie. Paris: Minuit, 1972.

-. The Ear of the Other: Otobiography, Transference, Translation. Trans. Avita Ronell. Lincoln: U of Nebraska P, 1985. Trans. of L'Oreille de l'autre: otobiographies, transferts, traductions. Montreal: V1b, 1982.

9. This is also the case of the so-called "Indian Notebooks 1969": based on the author's impressions of India (where he lived between 1968 and 1970), they take the shape of a travel narrative, the factuality of which is circumvented thanks to personal comments. However, the continuous and retrospective nature of this text (penned in 1971) only reinforces the idea that the heterogeneous form taken by the Notebooks is far from fortuitous or anecdotal. 
Hage, Ghassan. White Nation: Fantasies of White Supremacy in a Multicultural Society. Annandale NSW: Pluto, 1998.

Lefebvre, Henri. The Production of Space. Trans. Donald Nicholson-Smith. Oxford: Blackwell, 1991. Trans. of La Production de l'espace. Paris: Anthropos, 1974.

Lejeune, Philippe. "The Autobiographical Contract.” French Literary Theory Today. Ed. Tzvetan Todorov, trans. R. Carter. Cambridge: Cambridge UP, 1982. 192-222. Trans. of Le Pacte autobiographique. Paris: Seuil, 1975.

Marcus, Laura. Auto/biographical Discourses: Theory, Criticism, Practice. Manchester: Manchester UP, 1994.

Moore-Gilbert, Bart. Postcolonial Life-Writing: Culture, Politics and Self-Representation. London: Routledge, 2009.

-. "A Concern Peculiar to Western Man? Postcolonial Reconsiderations of Autobiography as a Genre." Postcolonial Poetics: Genre and Form. Ed. Patrick Crowley and Jane Hiddleston. Liverpool: Liverpool UP, 2011. 91-108.

REGARD, Frédéric. “"Géotobiographies' : Introduction aux géographies du soi.” L'Autobiographie littéraire en Angleterre (17 $7^{\text {ème }}$-20 ème siècles). Ed. Frédéric Regard. Saint-Étienne: PU Saint-Étienne, 2000. 11-33.

—. "Topologies of the Self: Space and Life-Writing." Mapping the Self: Space, Identity, Discourse in British Auto/Biography. Ed. Frédéric Regard. Saint-Étienne: PU Saint-Étienne, 2003. 15-30.

Riemer, Andrew. Review of the Notebooks 1970-2003. Sydney Morning Herald. 19 January 2006.

TOurnier, Michel. Journal extime. 2002. Paris: Gallimard, 2004.

White, Patrick. "The Prodigal Son." The Vital Decade: Ten Years of Australian Art and Letters. Ed. Geoffrey Dutton. 1958. Melbourne: Sun, 1968. 156-8. 